\title{
Paideusis
}

\section{Editorial Introduction to the Special Themed Issue : Contemplative Practice, Education, and Socio- Political Transformation (Part One)}

\section{Claudia Eppert and Daniel Vokey}

Volume 20, Number 2, 2012

Contemplative Practice, Education, and Socio-Political

Transformation (Part One)

URI: https://id.erudit.org/iderudit/1071825ar

DOI: https://doi.org/10.7202/1071825ar

See table of contents

Publisher(s)

Canadian Philosophy of Education Society

ISSN

0838-4517 (print)

1916-0348 (digital)

Explore this journal

Cite this document

Eppert, C. \& Vokey, D. (2012). Editorial Introduction to the Special Themed

Issue : Contemplative Practice, Education, and Socio- Political Transformation

(Part One). Paideusis, 20(2), 1-3. https://doi.org/10.7202/1071825ar 
Paideusis, Volume 20 (2012), No. 2, pp. 1-3

\title{
Editorial Introduction to Special Themed Issue: Contemplative Practice, Education, and Socio- Political Transformation (Part One)
}

\author{
CLAUDIA EPPERT AND DANIEL VOKEY \\ University of Alberta and University of British Columbia
}

The theme of this special issue is inspired by the marked rise of scholarly interest in contemplative studies in recent years. In our understanding, contemplative studies is a cross-disciplinary field of inquiry into the teachings offered and embodied by ancient wisdom texts and traditions, including their contemporary forms. ${ }^{1}$ We are particularly drawn to those wisdom traditions in which mind, body, and spirit are recognized as vitally interconnected, as are self, others, and the world; and in which cultivating wisdom involves practicing disciplines of the mind in/with the body, in community as well as in solitude. Contemplative studies considers what possibilities such teachings and disciplines might open up for rethinking contemporary educational theories, policies and practices in light of today's sociopolitical and environmental challenges. This process often involves dialogue across traditions and cultures on how we might live well with each other (including non-human sentient beings) and lightly on the earth.

In our view, inquiry into and communication across wisdom traditions promises greater insight into what specific forms of individual and collective transformation may give rise to more just, compassionate, and sustainable ways of life. We are concerned when contemplative disciplines are presented as purely individual practices with such benefits as personal growth and interpersonal effectiveness, and minimal connection to larger social, political, moral, and ecological issues. Conversely, we worry when efforts to effect positive social transformation fail to notice how ingrained habits of dualistic perceiving, feeling, thinking, and acting limit the potential benefits of political activism. We believe that the connections between the personal and the political involve complex hazards and opportunities that merit careful attention, hence our call for papers on the relationships among contemplative practice, education, and socio-political transformation. The large volume of submissions we received in response testifies to the increasing centrality of contemplative studies to educational discourse. In order to honor the significant interest in this topic, the next as well as this current issue of Paideusis will feature papers on this theme, although there will always be room to include contributions on other topics within philosophy of education.

The five articles in this issue illustrate different ways in which contemplative studies offer possibilities for rethinking education and schooling in contemporary times. The particular topics and concerns that each examines are identified in the authors' abstracts. Their differences notwithstanding,

\footnotetext{
1 A working definition and list of contemplative practices is provided by the Center for Contemplative Mind in Society, http://www.contemplativemind.org/practices/tree.

(C) Copyright 2012. The authors, Daniel Vokey and Claudia Eppert, assign to Paideusis the right of first publication and educational and non-profit institutions a non-exclusive license to use this document for personal use and in courses of instruction provided that the article is used in full and this copyright statement is reproduced. Any other usage is probibited without the express permission of the author.
} 
the articles also manifest common concerns that can be brought to light by considering how each addresses these three broad questions:

- What are the potential benefits of a particular contemplative practice, teaching, or tradition to those concerned with personal and social transformation?

- Under what conditions are those benefits likely to be realized and, conversely, what obstacles and challenges are presented by the particular characteristics of contemporary educational contexts?

- What actions are called for, in light of the above?

In his paper "Implementing Mindfulness: Practice as the Home of Understanding", Don Nelson presents a Buddhist account of mindfulness meditation as a path to insight and wisdom. His concern is that, when mindfulness is studied within the narrow paradigm of instrumental rationality that characterizes much scientific educational research, meditation will be conceptualized and taught in a more limited way than how it is understood and practiced within its traditional context. His recommendations therefore elaborate a general point that educators should resist such reductionism and maintain the view of mindfulness "as a practice that lives within a complex and evolving historical and cultural tradition kept alive by careful transmission from teacher to student".

In their article "'Just a Swinging Door" - Examining the Egocentric Misconception of Meditation", Antti Saari and Jani Pulkki draw first upon Foucault's description of ancient Greek practices of self-knowledge and self care, and then upon Hadot's account of ancient philosophy as a way of life, to remind us that Western contemplative disciplines were undertaken to transform the subjectivity of the practitioner toward a greater openness to truth. They then argue that this ideal is foreign to the modern western conceptions of philosophy that inherit an egoistic Liberal view of persons rooted in Cartesian dualism. As an antidote to the illusion that the self exists in isolation, Saari and Pulkki prescribe zazen-mindfulness of breathing as practiced within Zen Buddhism-and describe how experience unmediated by discursive intellectualizing dissolves the conceptual boundaries between self and world.

In his "Teaching as Contemplative Professional Practice", Thomas Falkenberg considers the benefits of mindfulness meditation as practiced in the Vipassana tradition, writing from the perspective of a teacher with professional moral responsibilities to act for the benefit of students. A key premise of his argument is that responsible teaching requires us to be aware of when and how we should interrupt our automatic or habitual patterns of perceiving, feeling, thinking and acting-for example, when we find ourselves stereotyping students. He articulates a conception of teaching as contemplative professional practice in which we are enjoined to train in mindfulness to develop the self-awareness and self-knowledge that in turn enables us to notice what we need to change.

In "Choosing to Love", Mary Jo Hinsdale considers the potential of contemplative disciplines to awaken a deep compassion that transcends ego-centred categories of "friend" and "enemy". Hinsdale sees in such compassion a way towards the mutually responsive relationships that authentic pedagogy requires, notwithstanding the unequal positions of faculty and students within academic and social power relationships. Through an account of Kelly Oliver's conception of witnessing, Hinsdale expounds an ethic of love, and then illustrates how to practice it. Theravada Buddhist teachings on three of the four "limitless abodes"-metta (loving-kindness), karuna (compassion), and upekkha (equanimity) — can serve as a practice vehicle through which educators may work towards more responsive and open-minded relationships with their students.

In "Recovering Ancient and Medieval Contemplative Taxonomies as an Alternative to Bloom's Taxonomy of Educational Objectives", Sean Steel considers how ancient Greek and Augustinian understandings of contemplative knowing emphasize a direct apprehension of wisdom, in which the gaze of the knower is receptive to what is in all its entirety. In marked contrast, modern schooling 
promotes a linear point-by-point practice of discursive, critical-analytic reasoning. With reference to Bloom's taxonomy, Steel illustrates the educational limitations of such modern lines of reasoning. He invites a renewed pursuit of wisdom through the reclamation of contemplative activity, and the reengagement with more complete taxonomies.

Each of these articles in its own way reveals that those who wish to enlist contemplative disciplines in the name of personal and social transformation are challenged to reconsider many of the philosophical assumptions, institutional structures, cultural norms, and pedagogical practices of modern western educational contexts. The taken-for-granted assumptions under question in this issue include Western understandings of instrumental rationality, body-mind dualism, sovereign individualism, and moral universalizability.

Finally, also included in this issue is a review by Barbara Bickel of Alyson Pryer's book Embodied Wisdom: Meditations on Memoir and Education. This review is timely for this issue, as Pryer explores possibilities for non-dual pedagogy with reference to Celtic and Asian wisdom.

We hope you enjoy this issue. Should you be interested in writing responses to any of these articles, or seek to be included in our database as a potential reviewer, please do not hesitate to contact us. Also, please stay tuned for our spring issue, in which we will continue this dialogue with new and exciting submissions! Looking ahead to Fall 2013, another special themed issue of Paideusis under the guest editorship of Heesoon Bai will feature contributions on the topic of education for compassion. Contributors will be participants from the March 2012 academic symposium that Heesoon organized with help and support from her colleagues, graduate students, and the Centre for Dialogue at Simon Fraser University, under the title Working Compassion, which was inspired by Karen Armstrong's "Charter for Compassion" initiative.

We wish to extend thanks and appreciation to our new copy-editor, James Bigari, and senior copy-editor Saskia Tait, for their hard work and attention to detail. Thanks are also due to SFU's Kevin Stranach for managing the technical side of the online publishing process, and to David Waddington for his service as Book Editor. We are grateful for the continued strong support Paideusis receives from Editorial Board members Ann Chinnery, Michelle Forrest, and Doug Simpson, respectively the Secretary-Treasurer, Past-President, and President of the Canadian Philosophy of Education Society (CPES). Heartfelt thanks to all those who generously volunteered their time and expertise to review the many submissions we received for this special themed issue. A deep bow of appreciation to one and all. 